\title{
The analysis of flour blends as affected by the behaviour of two different quality flours of triticale under different fertilizer treatments
}

\author{
${ }^{1}$ Erika Ács $-{ }^{1}$ Lajos Bóna $-{ }^{1}$ Bernadett Langó $-{ }^{1}$ Katalin Ács $-{ }^{2}$ Péter Pepó - ${ }^{1}$ István Mihály Petróczi \\ ${ }^{1}$ Cereal Research Non-Profit Co. Szeged, Hungary \\ ${ }^{1}$ University of Debrecen Faculty of Agricultural and Food Sciences and Environmental Management, \\ Institute of Crop Sciences, Debrecen, Hungary \\ erika.acs@gabonakutato.hu
}

\begin{abstract}
SUMMARY
Triticale is likely used in many countries in human consumption, due to its advantageous agronomical and nutritional properties mostly in blends. The baking quality of blends depends not just on the proportions of the used flours but also on their individual quality what can be influenced by fertilizer treatments.

22 flour blends were prepared with commercial wheat flour and triticale wholemeal flour in proportions from $0 \%$ to $100 \%$. The triticale was treated with different amount of fertilizers $\left(N_{30} P_{30} K_{30}, N_{60} P_{0} K_{0}\right)$. Changes of wet gluten contents and extensograph parameters of the blends were determined. The quality of blends significantly depends on the fertilizer treatment of triticale beside the proportions of the flours. When the $N_{60} P_{0} K_{0}$ treated triticale was used in blends, wet gluten and extensibility values were significantly higher, but in case of resistant to extensions $\left(R_{\text {max }}\right)$ the $N_{30} P_{30} K_{30}$ treated samples gave higher values. The measured values of wet gluten and extensibility were above the expected values (synergism), while in the case of resistance to extension the expected values were higher than the measured values (antagonism).
\end{abstract}

Keywords: triticale, fertilization, blends, wet gluten, extensograph quality

\section{ÖSSZEFOGLALÁS}

A tritikálé humán célú felhasználása elönyös agronómiai és táplálkozási tulajdonságai miatt sok országban közkedvelt, elsősorban keverékek komponenseként. A keverékek minösége nem csak a lisztfajtától, hanem annak egyéni minőségétöl is függ, melyet a termesztésekor alkalmazott mütrágyakezelés befolyásolhat.

22 lisztkeverék készült kommersz búzaliszt és teljes kiörlésü tritikálé liszt 0-100\% közötti arányaival. A tritikálé komponensek különbözö mütrágyakezelésben részesültek $\left(N_{30} P_{30} K_{30}, N_{60} P_{0} K_{0}\right)$. A nedves sikér és az extenzográfos paraméterek változásait vizsgáltuk. A keverékek minösége szignifikánsan függött a lisztkeverék arányokon túl a mütrágyakezeléstöl. $A N_{60} P_{0} K_{0}$ kezelésben részesült tritikálé tétellel készült keverékek nedves sikér mennyisége és extenzográfos nyújthatósága, az $N_{30} P_{30} K_{30}$ kezelésben részesült minták keverékeinek extenzográfos nyújtásellenállása $\left(R_{\max }\right)$ volt szignifikánsan magasabb. A nedves sikér értékek és extenzográfos nyújthatóságok a keverö lisztek matematikai átlagából képzett várt érték felettieknek mutatkoztak (szinergizmus), míg az extenzográfos nyújtásellenállás értékei a várt érték alattiak voltak (antogonizmus).

Kulcsszavak: tritikálé, mütrágyázás, keverékek, nedves sikér, extenzográfos minöség

\section{INTRODUCTION}

Triticale or ryewheat (Triticosecale) is a hybrid of wheat (Triticum aestivum L.) and rye (Secale cereale L.), a new cereal variety which was bred by humans. Triticale flours are used in the baking industry in many countries, due to its advantageous agronomical and nutritional properties as it has higher dietary fiber, arabinoxylan and mineral contents compared to that of wheat. It is well known that the gluten content and the baking quality of triticale are weaker than that of wheat flour (Leon et al., 2008). Therefore triticale is used mostly in blends (Lorenz and Ross, 1986; Naeem et al., 2002; Erekul and Kohn, 2006) with different proportions. Doxastakis et al. (2002) found that by adding 5$10 \%$ triticale can insure the same or even improve the bread volume and its texture compared to wheat bread. Seguchi et al. (1999) found that adding 18.3\% triticale causes the biggest bread volume. Others suggested higher amount of triticale proportions in order to receive better baking quality such as $40 \%$ (Saurer, 1985), 50\% (Serna-Saldivar et al., 2004) or 70\% (Tohver et al., 2005). The most common and used ratio in blends is the $50 \%$ wheat flour with maximum 50\% triticale flour where depending on the end-products both wholemeal triticale and white triticale flours can also be used (Peña and Amaya, 1992; Doxastakis et al., 2002; Tohver et al., 2005). The sensory qualities of breads made from blends were adequate for human consumptions, with good storage life and pleasant flavour (Tohver et al., 2000; Zecevic et al., 2010). Blends with higher amount of bran content improve the nutritional value of the products but decrease the bread volume (Sipos et al., 2012). In the case of pastas it was found that $30 \%$ of wheat flour can be replaced with wholemeal triticale flour without diminished quality (Kalnina et al., 2015).

The size and the applied technologies of bakeries can also be important factors when making blends. In ,smaller” bakeries where goods are processed manually in general, the weaker gluten quality does not cause big issues during the kneading procedure compared to the „bigger” bakeries where industrial applications are used. According to Legesse (2013) unique baking technologies should be developed and applied in those cases when triticale is used in higher proportions taking into account the unique properties of the used triticales.

The baking quality of blends depends not just on the proportion of the flours but also on their individual quality. The technological properties of triticale can be 
significantly influenced by fertilization (Knapowski et al., 2012). This effect just slightly influences the rheological qualities of white triticale flour but it has a significant effect on the wholemeal triticale flours (Ács et al., 2016).

The goal of this work was to study flour blends as affected by the behaviour of two different quality flours of a Hungarian triticale variety under different fertilizer treatments.

\section{MATERIAL AND METHODS}

\section{Triticale samples}

One Hungarian winter triticale variety (GK Szemes) was analyzed. The triticale was grown at Fülöpszállás (2014), Hungary, the test site of the Cereal Research Non-profit Company, where a long-term fertilization trial was carried out. Fertilizers with different amounts $\left(0,30,60,90 \mathrm{~kg} \mathrm{ha}^{-1}\right)$ of nitrogen $(\mathrm{N})$, phosphorus $(\mathrm{P})$ and potassium $(\mathrm{K})$ level were used. Samples, treated with higher $\mathrm{N}$ fertilizer without $\mathrm{PK}\left(\mathrm{N}_{60} \mathrm{P}_{0} \mathrm{~K}_{0}\right)$ and treated with moderate level of N,P,K $\left(\mathrm{N}_{30} \mathrm{P}_{30} \mathrm{~K}_{30}\right)$ fertilizer were used in order to make blends. Samples were milled by stone mill (Flourmill A 500MSM), and the wholemeal triticale flours (particle sizes: $12 \%$ of

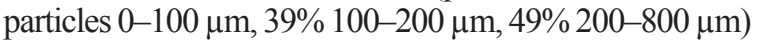
were tested.

\section{Flour blends}

Commercial (all purpose) white wheat flour (WF) was used to make flour blends with the triticale wholemeals (Tc WM). Eleven blends were made in proportions ranging from $0 \%$ to $100 \%$, and the proportion of triticale wholemeal in each sample was increased step by step by $10 \%$. The experiments were carried out in duplicate.

\section{Quality analysis}

Wet gluten was measured by ICC 106/2. The dough rheological properties were examined by Brabender Farinograph and Brabender Extensograph following the usage of the ICC 115/1 and ICC 114/1 methods (Brabender $\mathrm{GmbH}$ and Co. KG, Germany).

\section{Statistical analysis}

The analysis of variance (ANOVA) was calculated by STATISTICA 12 (developed by StatSoft Inc., 2013) software. The significant differences of means were determined by Fischer's protected LSD test at $\mathrm{p}<0.05$.

\section{RESULTS}

Wet gluten content and extensographic parameters, such as resistance to extension and extensibility were analyzed in the present study. The results of the quality tests of the different blends are shown in Table 1.

Changes of quality parameters in flour blends as affected by the behaviour of different wholemeal triticale from different fertilizer treatments

\begin{tabular}{|c|c|c|c|c|}
\hline \multirow[b]{2}{*}{ Blends } & & \multirow[b]{2}{*}{$\begin{array}{l}\text { Wet gluten } \\
(\%)\end{array}$} & \multicolumn{2}{|c|}{ Extensograph } \\
\hline & & & $\begin{array}{l}\text { Resistance to extension } \\
\mathrm{R}_{\max } 135^{\prime}(\mathrm{BU}) \\
\end{array}$ & $\begin{array}{c}\text { Extensibility } \\
(\mathrm{mm})\end{array}$ \\
\hline $100 \% \mathrm{WF}+0 \% \mathrm{WM} \mathrm{Tc}\left(\mathrm{N}_{60} \mathrm{P}_{0} \mathrm{~K}_{0}\right)$ & & $26.4 n$ & $450 \mathrm{~g}$ & $154 \mathrm{ijk}$ \\
\hline $90 \% \mathrm{WF}+10 \% \mathrm{WM} \mathrm{Tc}\left(\mathrm{N}_{60} \mathrm{P}_{0} \mathrm{~K}_{0}\right)$ & & $25.6 \mathrm{mn}$ & $433 f g$ & $160 \mathrm{k}$ \\
\hline $80 \% \mathrm{WF}+20 \% \mathrm{WM} \mathrm{Tc}\left(\mathrm{N}_{60} \mathrm{P}_{0} \mathrm{~K}_{0}\right)$ & & $25.31 \mathrm{mn}$ & $348 d$ & $152 \mathrm{ijk}$ \\
\hline $70 \% \mathrm{WF}+30 \% \mathrm{WM} \mathrm{Tc}\left(\mathrm{N}_{60} \mathrm{P}_{0} \mathrm{~K}_{0}\right)$ & & $24.4 \mathrm{klmn}$ & $318 \mathrm{~d}$ & $157 \mathrm{jk}$ \\
\hline $60 \% \mathrm{WF}+40 \% \mathrm{WM} \mathrm{Tc}\left(\mathrm{N}_{60} \mathrm{P}_{0} \mathrm{~K}_{0}\right)$ & & 23.3jklm & $268 b c$ & $155 \mathrm{jk}$ \\
\hline $50 \% \mathrm{WF}+50 \% \mathrm{WM} \mathrm{Tc}\left(\mathrm{N}_{60} \mathrm{P}_{0} \mathrm{~K}_{0}\right)$ & & $22.7 \mathrm{jkl}$ & $217 \mathrm{a}$ & 151ijk \\
\hline $40 \% \mathrm{WF}+60 \% \mathrm{WM} \mathrm{Tc}\left(\mathrm{N}_{60} \mathrm{P}_{0} \mathrm{~K}_{0}\right)$ & & 21.5hij & $216 \mathrm{a}$ & $134 \mathrm{~h}$ \\
\hline $30 \% \mathrm{WF}+70 \% \mathrm{WM}$ Tc $\left(\mathrm{N}_{60} \mathrm{P}_{0} \mathrm{~K}_{0}\right)$ & & 21.5hij & $235 \mathrm{ab}$ & $126 \mathrm{gh}$ \\
\hline $20 \% \mathrm{WF}+80 \% \mathrm{WM}$ Tc $\left(\mathrm{N}_{60} \mathrm{P}_{0} \mathrm{~K}_{0}\right)$ & & 20.8ghij & $227 \mathrm{ab}$ & $127 \mathrm{gh}$ \\
\hline $10 \% \mathrm{WF}+90 \% \mathrm{WM} \mathrm{Tc}\left(\mathrm{N}_{60} \mathrm{P}_{0} \mathrm{~K}_{0}\right)$ & & $18.6 \mathrm{efg}$ & $253 \mathrm{ab}$ & $114 \mathrm{f}$ \\
\hline $0 \% \mathrm{WF}+100 \% \mathrm{WM} \mathrm{Tc}\left(\mathrm{N}_{60} \mathrm{P}_{0} \mathrm{~K}_{0}\right)$ & & $17.2 \mathrm{e}$ & $324 d$ & 99de \\
\hline $100 \% \mathrm{WF}+0 \% \mathrm{WM} \mathrm{Tc}\left(\mathrm{N}_{30} \mathrm{P}_{30} \mathrm{~K}_{30}\right)$ & & $26.2 n$ & $438 f g$ & $147 \mathrm{ij}$ \\
\hline $90 \% \mathrm{WF}+10 \% \mathrm{WM} \mathrm{Tc}\left(\mathrm{N}_{30} \mathrm{P}_{30} \mathrm{~K}_{30}\right)$ & & $24.6 \mathrm{klmn}$ & $398 \mathrm{ef}$ & $145 \mathrm{i}$ \\
\hline $80 \% \mathrm{WF}+20 \% \mathrm{WM} \mathrm{Tc}\left(\mathrm{N}_{30} \mathrm{P}_{30} \mathrm{~K}_{30}\right)$ & & $22.5 \mathrm{ijk}$ & 401ef & $131 \mathrm{gh}$ \\
\hline $70 \% \mathrm{WF}+30 \% \mathrm{WM} \mathrm{Tc}\left(\mathrm{N}_{30} \mathrm{P}_{30} \mathrm{~K}_{30}\right)$ & & 20.0fghi & $358 \mathrm{de}$ & $124 \mathrm{fg}$ \\
\hline $60 \% \mathrm{WF}+40 \% \mathrm{WM} \mathrm{Tc}\left(\mathrm{N}_{30} \mathrm{P}_{30} \mathrm{~K}_{30}\right)$ & & 19.0efgh & $345 \mathrm{~d}$ & $116 f$ \\
\hline $50 \% \mathrm{WF}+50 \% \mathrm{WM} \mathrm{Tc}\left(\mathrm{N}_{30} \mathrm{P}_{30} \mathrm{~K}_{30}\right)$ & & $17.4 \mathrm{ef}$ & $314 \mathrm{~cd}$ & $104 \mathrm{e}$ \\
\hline $40 \% \mathrm{WF}+60 \% \mathrm{WM} \mathrm{Tc}\left(\mathrm{N}_{30} \mathrm{P}_{30} \mathrm{~K}_{30}\right)$ & & $13.8 \mathrm{~d}$ & $324 d$ & $92 \mathrm{~d}$ \\
\hline $30 \% \mathrm{WF}+70 \% \mathrm{WM} \mathrm{Tc}\left(\mathrm{N}_{30} \mathrm{P}_{30} \mathrm{~K}_{30}\right)$ & & $9.8 \mathrm{c}$ & $339 \mathrm{~d}$ & $80 \mathrm{c}$ \\
\hline $20 \% \mathrm{WW}+80 \% \mathrm{WM} \mathrm{Tc}\left(\mathrm{N}_{30} \mathrm{P}_{30} \mathrm{~K}_{30}\right)$ & & $5.0 \mathrm{~b}$ & $358 \mathrm{de}$ & $71 \mathrm{c}$ \\
\hline $10 \% \mathrm{WW}+90 \% \mathrm{WM} \mathrm{Tc}\left(\mathrm{N}_{30} \mathrm{P}_{30} \mathrm{~K}_{30}\right)$ & & $2.4 \mathrm{a}$ & $434 \mathrm{fg}$ & $61 b$ \\
\hline $0 \% \mathrm{WW}+100 \% \mathrm{WM} \mathrm{Tc}\left(\mathrm{N}_{30} \mathrm{P}_{30} \mathrm{~K}_{30}\right)$ & & $1.5 \mathrm{a}$ & $575 \mathrm{~h}$ & $49 \mathrm{a}$ \\
\hline Blends of WM Tc $\left(\mathrm{N}_{60} \mathrm{P}_{0} \mathrm{~K}_{0}\right)$ & Mean & $22.5 \mathrm{~B}$ & $298.8 \mathrm{~A}$ & $138.8 \mathrm{~B}$ \\
\hline Blends of WM Tc $\left(\mathrm{N}_{30} \mathrm{P}_{30} \mathrm{~K}_{30}\right)$ & Mean & $14.7 \mathrm{~A}$ & $389.2 \mathrm{~B}$ & $101.7 \mathrm{~A}$ \\
\hline
\end{tabular}

Note: WF - White wheat flour, WM Tc - Triticale wholemeal. Means followed by different letters are significantly different where significance is performed by Fisher LSD test. 


\section{Changes of wet gluten content of the blends}

The wet gluten (WG) contents of the blends were always lower compared to that of wheat flour, but the results also depended on the type of fertilizer treatment and the proportion of flour. The higher amount of nitrogen fertilizer improved the WG content. In the blend series with higher nitrogen $\left(\mathrm{N}_{60}\right)$ treatment, the WG values were significantly higher than in the series with lower $\left(\mathrm{N}_{30}\right)$ treatment. Proportion $\times$ fertilizer interaction was statistically significant. Compared to the wheat flour the WG contents were significantly reduced at $50 \%$ proportion in case of $\mathrm{N}_{60} \mathrm{P}_{0} \mathrm{~K}_{0}$ series but was significantly reduced by adding $20 \%$ or more triticale flour in the case of $\mathrm{N}_{30} \mathrm{P}_{30} \mathrm{~K}_{30}$. When $30 \%$ or more triticale was added to the blends, the higher nitrogen $\left(\mathrm{N}_{60} \mathrm{P}_{0} \mathrm{~K}_{0}\right)$ treatment showed significantly higher wet gluten content. The wet gluten content of $100 \% \mathrm{~N}_{30} \mathrm{P}_{30} \mathrm{~K}_{30}$ triticale sample was minimal (1.5\%), and significantly lower than the value of $100 \% \mathrm{~N}_{60} \mathrm{P}_{0} \mathrm{~K}_{0}$ triticale (17.2\%). The blends showed a positive synergistic effect in the case of WG (Figure 1), which means that the WG content of the blends were always higher than the expected values (the weighted average of the two flours). In the series of $\mathrm{N}_{30} \mathrm{P}_{30} \mathrm{~K}_{30}$ slightly negative effect could be observed when higher proportion triticale was used (80-90\%).

Figure 1: Changes of wet gluten content in flour blends as affected by the behaviour of different wholemeal triticale under different fertilizer treatments

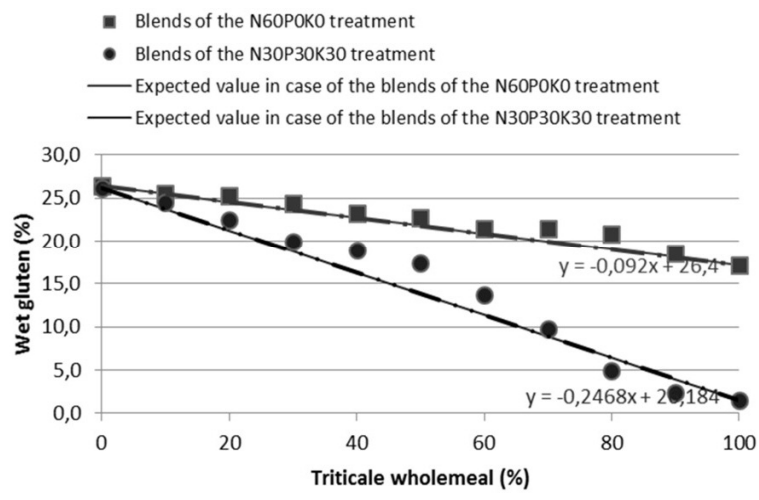

Changes of extensograph resistance to extension of the blends

The different fertilizer treatments significantly affected the resistance to extension of extensograph test in the flour blends. Samples treated with a moderate level of NPK fertilizers $\left(\mathrm{N}_{30} \mathrm{P}_{30} \mathrm{~K}_{30}\right)$ showed higher resistance to extension.

By increasing the proportion of the added triticale flour in the blends, the resistance to extension decreased significantly (Figure 2). This effect changed whenever higher proportion $(90 \%)$ triticale was added. The resistance to extension values of $\mathrm{N}_{30} \mathrm{P}_{30} \mathrm{~K}_{30}$ triticale was much higher $(575 \mathrm{BU})$ than the $\mathrm{N}_{60} \mathrm{P}_{0} \mathrm{~K}_{0}$ triticale's (324 BU), and the value of wheat flour was between the two triticale samples (438 BU). Blends with the $\mathrm{N}_{30} \mathrm{P}_{30} \mathrm{~K}_{30}$ triticale showed significantly higher resistance to extension over $20 \%$ triticale proportions than compared to the $\mathrm{N}_{60} \mathrm{P}_{0} \mathrm{~K}_{0}$ series.
Figure 2: Changes of extensograph resistance to extension

$\left(R_{\max } 1^{\prime} 5^{\prime}\right)$ in flour blends as affected by the behaviour of different wholemeal triticale under different fertilizer treatments

Blends of the $\mathrm{N} 60 \mathrm{POKO}$ treatment

- Blends of the N30P30K30 treatment

Expected value in case of the blends of the N6OPOKO treatment

Expected value in case of the blends of the N3OP30K30 treatment

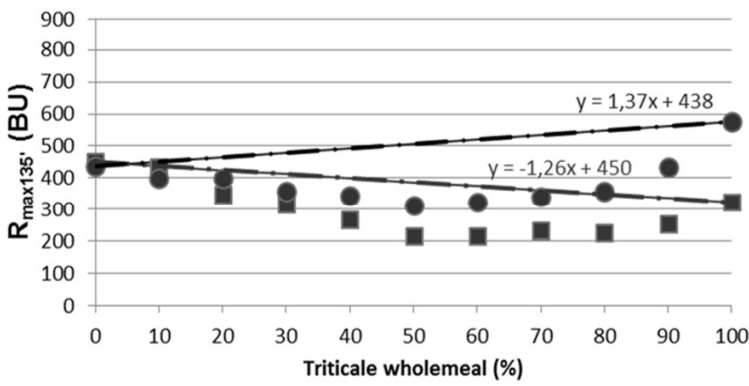

The values of extensograph resistance to extension showed antagonism effects depending on the fertilizer treatment.

\section{Changes of the extensograph extensibility of the blends}

The different fertilizer treatments also significantly affected the extensibility values of the flour blends (Figure 3). The increased triticale proportion continually decreased the extensibility values. These values were higher in the $\mathrm{N}_{60} \mathrm{P}_{0} \mathrm{~K}_{0}$ series. A positive synergetic effect could be observed in both blend series. In the $\mathrm{N}_{30} \mathrm{P}_{30} \mathrm{~K}_{30}$ series the observed extensibility values varied less from the expected values, while this synergetic effect was higher in the $\mathrm{N}_{60} \mathrm{P}_{0} \mathrm{~K}_{0}$ blends.

Figure 3: Changes of extensograph extensibility in flour blends as affected by the behaviour of different wholemeal triticale under different fertilizer treatments

- Blends of the N60POKO treatment

- Blends of the N30РзоK30 treatment

- Expected value in case of the blends of the N6OPOKO treatment

- Expected value in case of the blends of the N30P30K30 treatment

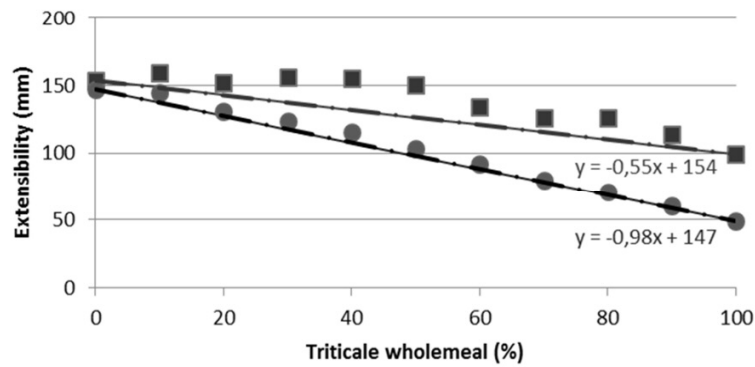

\section{DISCUSSION}

Flour blends were made with one triticale variety that was treated with different fertilizers to determine the changes in quality parameters. Our experiments showed that the quality of the blends significantly depends on the fertilizer treatment of triticale beside the proportions of the flours in the blends. 
Wet gluten content is a major parameter that fundamentally determines the quality of flours. In triticale-wheat blends this parameter will always be decreased due to the originally lower wet gluten content of triticale. But significant differences can also be measured according to the type of fertilizer treatment. In the case of $\mathrm{N}_{60} \mathrm{P}_{0} \mathrm{~K}_{0}$ usage the wet gluten content of both triticale and the blends were significantly higher than in the triticale flours treated with $\mathrm{N}_{30} \mathrm{P}_{30} \mathrm{~K}_{30}$ fertilizer. It seems that the PK fertilizer decreases the amount of washable wet gluten while giving $\mathrm{N}$ fertilizer to the triticale would improve the wet gluten content. These changes can possibly be explained by the presence of certain fibres, since due to the different level of PK fertilizer the amount and maybe the type of fibre components can be changed. These components also determine the chance of washing out the wet gluten content (Rosicka-Kaczmarek et al., 2016).

An important result of this experiment is that there is no positive relationship between the wet gluten content and the resistant to extension (dough stability) when triticale is used compared to wheat flours. When the proportion of triticale is higher than $50 \%$ in the blends, the values of Rmax increase though the wet gluten content henceforward decreases. This means that even despite the very low WG content, the blends can be processed well in the industrial baking process because of its higher resistance to extension. Due to the same reason blends with the $\mathrm{N}_{30} \mathrm{P}_{30} \mathrm{~K}_{30}$ treated triticale are more suitable in the industrial processes, as they have higher Rmax values.

The measured values of wet gluten and extensibility are above the expected values (synergism), while in the case of resistance to extension antagonism can be observed. The reason behind these synergetic and antagonistic effects can be explained by the interactions of the blend components (protein - protein, protein fibre interactions). But for the better understanding of these effects, further technological and analytical studies are necessary to be carried out.

\section{ACKNOWLEDGMENTS}

This research was supported by the GOP 1.1.1 11- 2012-0044 project.

\section{REFERENCES}

Ács E.-Bóna L.-Langó B.-Véha A.-Pepó P.-Petróczi I. M. (2016): Szegedi tritikálé fajták fontosabb minőségi jellemzőinek változása mütrágyázási tartamkísérletben. Agrártudományi Közlemények. 67: 21-26.

Doxastakis, G.-Zafiriadis, I.-Irakli, M.-Marlani, H.-Tananaki, C. (2002): Lupin, soya and triticale addition to wheat flour doughs and their effect on rheological properties. Food Chemistry. 77: 219-227.

Erekul, O.-Kohn, W. (2006): Effect of weather and soil conditions an yield cpmponents and bread-making quality of winter wheat (Triticum aestivum L.) and winter triticale (x Triticosecale Wittm.) varieties in north-east Germany. Journal of Agronomy and Crop Science. 192: 452-464

ICC 106/2: Working Method for the Determination of the Wet Gluten in Wheat Flour.

ICC 114/1: Method for using the Brabender Extensograph.

ICC 115/1: Method for Using the Brabender Farinograph.

Kalnina, S.-Rakcejeva, T.-Kunkulberga, D.-Galoburda, R. (2015): Rheological properties of whole wheat and whole triticale flour blends for pasta production. Agronomy Research. 13. 4: 948-955.

Knapowski, T.-Ralcewicz, M.-Spychaj-Fabisiak, E.-Murawska, B. (2012): Effect of the rate of nitrogen and zinc on the zinc and copper accumulation in grain of spring triticale cultivar kargo. Journal of Elementology. 17: 421-429.

Legesse, W. (2013): Triticale adaptation and competence assessment result in the highlands of Ethiopia. $8^{\text {th }}$ International Triticale Symposium. Gent. Belgium. 32.

Leon, A. E.-Barrera, G. N.-Perez, G. T.-Ribotta, P. D.-Rosell, C. M. (2007): Effect of damaged starch levels on flour-thermal behaviour and bread staling. European Food Research and Technology. 224: 187-192.

Lorenz, K.-Ross, M. (1986): Baking properties of NZ grown triticales. Food Tech. New Zealand. 8: 35-39.
Naeem, H. A.-Darvey, N. L.-Gras, P. W.-Macrichie, F. (2002): Mixing propeties, baking potential, and functionality changes in storage proteins during dough development of triticale-wheat flour blends. Cereal Chemistry. 79: 332-339.

Pena, R. J.-Amaya, A. (1992): Milling and breadmaking properties of wheat and triticale grain blends. Journal of the Science of Food and Agriculture. 60: 483-487.

Rosicka-Kaczmarek, J.-Komisarczyk, A.-Nebesny, E.-Makowski, B. (2016): The influence of arabinoxylans ont he quality of grain industry products. Eur. Food Res. Technol. 242: 295-303.

Saurer, W. (1985): Untersuchungen über Backeigenschaften von Triticalemehl in Mischung mit Weizenmehl. Die Mühle \& Mischfuttertechnik. 2: 13-15.

Seguchi, M.-Ishihara, C.-Yoshino, Y.-Nakatsuka, K.-Yoshihira, T. (1999): Breadmaking properties of triticale flour with wheat flour and relationship to amylase activity. Journal of Food Science. 64: 582-586.

Serna-Saldivar, S. O.-Guajdaro-Flores, S.-Viesca-Rios, R. (2004): Potential of triticale as a substitute for wheat in flour tortilla production. Cereal Chemistry. 81: 220-225.

Sipos P.-Győri Z.-Kruppa J.-Sándor M.-Kovács B. (2012): Gabonaalapú termékek táplálkozási értékének javítási lehetőségei. Agrártudományi Közlemények. 49: 275-278.

Tohvar, M.-Kann, A.-Täht, R.-Mihhalevski, A.-Hakman, J. (2005): Quality of triticale cultivars suitable for growing and breadmaking in northern condition. Food Chemistry. 89: 125-132.

Tohver, M.-Täht, R.-Kann, A.-Rahnu, I. (2000): Investigation of seed storage protein and bread-making quality of triticale. Acta Agronomica Hungarica. 48. 1: 41-49.

Zecevic, V.-Knezevic, D.-Boskovic, J.-Milenkovic, S. (2010). Effect of nitrogen and ecological factors on quality of winter triticale cultivars. Genetika. 42: 465-474. 